\title{
A Novel Picornavirus Discovered in White Leg Shrimp Penaeus vannamei
}

\author{
Shuang Liu ${ }^{1} \mathbb{D}$, Tingting $X u^{1}$, Chong Wang ${ }^{1}$, Tianchang Jia ${ }^{1}$ and Qingli Zhang ${ }^{1,2, *(\mathbb{D})}$ \\ 1 Qingdao Key Laboratory of Mariculture Epidemiology and Biosecurity, Key Laboratory of Maricultural \\ Organism Disease Control, Ministry of Agriculture, Yellow Sea Fisheries Research Institute, \\ Chinese Academy of Fishery Sciences, Qingdao 266071, China; liushuang@ysfri.ac.cn (S.L.); \\ xutingting83@163.com (T.X.); wangchongyilin@163.com (C.W.); jiatc2021@163.com (T.J.) \\ 2 Laboratory for Marine Fisheries Science and Food Production Processes, Pilot National Laboratory for Marine \\ Science and Technology, Qingdao 266071, China \\ * Correspondence: zhangq1@ysfri.ac.cn; Tel.: +86-532-8582-3062 (ext. 812)
}

Citation: Liu, S.; Xu, T.; Wang, C.; Jia, T.; Zhang, Q. A Novel Picornavirus Discovered in White Leg Shrimp Penaeus vannamei. Viruses 2021, 13, 2381. https://doi.org/10.3390/ v13122381

Academic Editor: Tae-Jin Choi

Received: 23 October 2021

Accepted: 23 November 2021

Published: 28 November 2021

Publisher's Note: MDPI stays neutral with regard to jurisdictional claims in published maps and institutional affiliations.

Copyright: (c) 2021 by the authors. Licensee MDPI, Basel, Switzerland This article is an open access article distributed under the terms and conditions of the Creative Commons Attribution (CC BY) license (https:// creativecommons.org/licenses/by/ $4.0 /)$

\begin{abstract}
Global shrimp farming is increasingly threatened by various emerging viruses. In the present study, a novel picornavirus, Penaeus vannamei picornavirus (PvPV), was discovered in moribund White leg shrimp (Penaeus vannamei) collected from farm ponds in China in 2015. Similar to most picornaviruses, $\mathrm{PvPV}$ is non-enveloped RNA virus, with a particle diameter of approximately $30 \mathrm{~nm}$. The sequence of the positive single-stranded RNA genome with a length of 10,550 nts was characterized by using genome sequencing and reverse transcription PCR. The existence of PvPV related proteins was further proved by confirmation of viral amino acid sequences, using mass spectrometry analysis. Phylogenetic analysis based on the full-length genomic sequence revealed that PvPV was more closely related to the Wenzhou shrimp virus 8 than to any other dicistroviruses in the order Picornavirales. Genomic sequence conservative domain prediction analysis showed that the PvPV genome encoded a large tegument protein UL36, which was unique among the known dicistroviruses and different from other dicistroviruses. According to these molecular features, we proposed that PvPV is a new species in the family Dicistroviridae. This study reported the first whole-genome sequence of a novel and distinct picornavirus in crustaceans, $P v P V$, and suggests that further studies of $P v P V$ would be helpful in understanding its evolution and potential pathogenicity, as well as in developing diagnostic techniques.
\end{abstract}

Keywords: Penaeus vannamei picorna viruses (PvPV); Picornavirales; Dicistroviridae; Penaeus vannamei; shrimp

\section{Introduction}

Viral diseases of Penaeus vannamei are important restrictive considerations in the shrimp farming industry in the world [1,2]. Major P. vannamei viruses impacting global shrimp farming to date have included white spot syndrome virus (WSSV) [3,4], covert mortality nodavirus (CMNV) [5], infectious hypodermal and hematopoietic necrosis virus (IHHNV) [6], Taura syndrome virus (TSV) [7], yellow head disease virus (YHV) [8], infectious myonecrosis virus (IMNV) [9] and Decapod iridescent virus 1 (DIV1). Recently, global shrimp farming has been increasingly threatened by emerging viruses, and the diseased shrimp individuals are often infected by more than one species of virus [10-12]. The genomes of the major shrimp viruses have now been fully sequenced, and the viruses with published genomes include WSSV [13,14], CMNV [15], IHHNV [16], TSV [17], YHV [18], shrimp hepatopancreatic parvovirus (HPV) [19,20], Penaeus vannamei nodavirus $(P v N V)$ [21] and IMNV [22]. Further studies on the genome sequence of shrimp viruses would be helpful in relation to their evolution, diagnostic techniques and control strategies.

The order Picornavirales has undergone a significant expansion in recent years, due principally to the identification of previously unknown picornaviruses discovered in ver- 
tebrates, arthropods, algae, humans, insects and plants using "next-generation" sequencing [23]. The members of Picornavirales have non-enveloped icosahedral virions about $30 \mathrm{~nm}$ in diameter, with a pseudo- $\mathrm{T}=3$ (abbreviated " $\mathrm{p}=3^{\prime \prime}$ ) structure [24]. The existence of the Hel-Pro-Pol core replicative module, including the "Hel" domain (a superfamily III helicase), "Pro" domain (a chymotrypsin-like proteinase) and "Pol" domain (a super-family I RNA-dependent RNA polymerase (RdRp)), has proved to be a primary feature of picornavirus genomes [25-29]. The CP module encoded upstream of the Hel-Pro-Pol module uniquely discriminates the members of the order Picornavirales from other picorna-like viruses [24]. Moreover, some virions of the viruses in the family Picornaviridae additionally include a small protein, VP4, encoded upstream of the CP module in the polyprotein [30,31]. The diversity of genomic structure indicates the ever-increasing genetic diversity of picornaviruses. However, the biological significance of many newly discovered picornaviruses is still unknown.

Taura syndrome virus (TSV) was the first characterized picorna virus infecting an invertebrate, P. vannamei, other than an insect [32]. Taura syndrome caused by TSV is one of the major diseases in penaeid shrimp and has impacted the shrimp farming industry in the past decade in some shrimp farming countries [33]. The main host of TSV was P. vannamei; in addition, it has also been reported to infect other penaeid shrimp species [34]. TSV primarily affected P. vannamei and P. stylirostris in the Americas at the beginning and then spread to farming of $P$. vannamei in Southeast Asia, where it has been responsible for acute mortality levels among farmed penaeid shrimp in Taiwan [35,36].

In this paper, we describe the genome sequence, morphological features and phylogenetic relationships of a novel picorna virus discovered in P. vannamei sampled from a farm in China in 2015. Based on the evidence obtained in the present study supporting a new virus species, we suggest a name, P. vannamei picornavirus (PvPV), for this virus.

\section{Materials and Methods}

\subsection{Shrimp Samples and Ethics Statement}

On 15 July 2015, diseased juvenile $P$. vannamei individuals (body length $5-7 \mathrm{~cm}$, NO. 20150715007) with the same disease syndrome were sampled from a shrimp farm pond in Weifang, Shandong Province, China. The hepatopancreas tissues of the sampled individuals were fixed in $2.5 \%$ glutaraldehyde solution (Sinopharm, Beijing, China) for transmission electron microscope observation, and the remaining parts of the diseased shrimp sample NO. 20150715007 were preserved at $-80{ }^{\circ} \mathrm{C}$ for viral isolation and metaviromic analysis. All the protocols of shrimp handling and sampling were approved by the Animal Care and Ethics Committee, Yellow Sea Fisheries Research Institute, Chinese Academy of Fishery Sciences (approval code: YSFRI-2015007).

\subsection{Transmission Electron Microscopy (TEM) Analysis}

The $P$. vannamei hepatopancreas tissues were first fixed in $2.5 \%$ glutaraldehyde in $0.1 \mathrm{M}$ PBS ( $\mathrm{pH} 7.4$ ) for $24 \mathrm{~h}$ at $4{ }^{\circ} \mathrm{C}$. Secondly, $1 \%$ osmium tetroxide was used for $2 \mathrm{~h}$ for further fixing of the sample. The sample was then embedded in Spurr's resin for preparing ultrathin sections $(50 \mathrm{~nm})$. The ultrathin sections and the purified viral particles were stained with uranyl acetate and lead citrate, and examined using a JEOL JEM-1200 electron microscope (Jeol Solutions for Innovation, Peabody, MA, USA).

\subsection{Virus Purification}

Purification of viral particles was conducted according to a previously reported protocol with a minor revision [37]. The samples of shrimp were homogenized in TN buffer (20 mM Tris/ $\mathrm{HCl}, 400 \mathrm{mM} \mathrm{NaCl}, \mathrm{pH}=7.4)$ and clarified at $1400 \times \mathrm{g}$ for $15 \mathrm{~min}$ to gather the supernatant. The pellets were homogenized again in $10 \mathrm{~mL}$ TN buffer and centrifuged at $8000 \times g$ for $15 \mathrm{~min}$ at $4{ }^{\circ} \mathrm{C}$. The supernatant was clarified for a second time at $10,000 \times g$ for $25 \mathrm{~min}$. The final supernatant was then centrifuged at 120,000 $\times g$ for $5 \mathrm{~h}$ (Ultracentrifuge CP100WX; Hitachi, Tokyo, Japan). TN buffer was used to suspend the pellet. 


\subsection{RNA Extraction, Library Construction and Virome Sequencing}

Total RNA of the viral extracts was prepared by using Trizol reagent kit (Invitrogen, Carlsbad, CA, USA) following the kit's protocol. The quality of purified RNA was assessed and determined by using Agilent 2100 Bio-analyzer and RNase-free agarose gel electrophoresis, respectively. mRNA was enriched from the total RNA using Ribo-Zero ${ }^{\mathrm{TM}}$ Magnetic Kit (Epicentre, Madison, WI, USA). The enriched mRNA was fragmented into short fragments and reverse transcribed into first-strand cDNA. Second-strand cDNA was then synthesized by amplification in vitro. Next, the cDNA fragments were purified, end-repaired, added with poly(A) and ligated to Illumina sequencing adapters. Finally, the second-strand cDNA was size-selected via agarose gel electrophoresis, amplified by PCR, and sequenced.

\subsection{Assembling and Phylogenetic Analysis}

Trinity, a short reads assembling program, was used to finish genome assembling [38]. The sequence of $\mathrm{PvPV}$ was submitted for a BLAST (National Center for Biotechnology Information) search, and highly similar matches were included in the dataset for phylogenetic analysis. The complete genome sequence was aligned with Clustal_W as implemented in MEGA 6.0 [39] using the default settings. The alignment file was checked visually for alignment gaps and missing data. A phylogenetic tree was then reconstructed by the neighbor-joining method with bootstrap analysis (1000 replicates) using MEGA 6.0.

\subsection{Viral RNA Extraction and cDNA Synthesis}

Total RNA was prepared from the purified virus suspension using Viral Genome RNA Extraction Kit (Tiangen, Beijing, China), and the quality and quantity of the nucleic acids were measured with the NanoDrop 2000c Spectrophotometer. Then, final concentrations of $100-200 \mathrm{ng} / \mu \mathrm{L}$ of the viral-RNA samples were adjusted for cDNA preparation. The primers used for synthesis of the first-strand cDNA are listed in Table 1.

Table 1. Primer used for confirmation of the whole genome of Penaeus vannamei picornavirus.

\begin{tabular}{|c|c|c|c|c|}
\hline $\begin{array}{c}\text { Gene } \\
\text { Fragments }\end{array}$ & Primer Code & $\begin{array}{l}\text { PCR Annealing } \\
\text { Temperature }\end{array}$ & Primer Sequence $\left(5^{\prime}-3^{\prime}\right)$ & Size (bp) \\
\hline \multirow{2}{*}{1} & RNA-F1 & \multirow{2}{*}{$48^{\circ} \mathrm{C}$} & ATCCACGGAAAGAGCC & \multirow{2}{*}{$1002 \mathrm{bp}$} \\
\hline & RNA-R1 & & TAGCGGAATGCGACAA & \\
\hline \multirow{2}{*}{2} & RNA-F2 & \multirow{2}{*}{$45^{\circ} \mathrm{C}$} & CTGCCCTTTGCCGTCTTC & \multirow{2}{*}{$1749 \mathrm{bp}$} \\
\hline & RNA-R2 & & CTGAGTGTCATTGTCTTGGA & \\
\hline \multirow{2}{*}{3} & RNA-F3 & \multirow{2}{*}{$50{ }^{\circ} \mathrm{C}$} & CGTTCCCATAAGGACCCA & \multirow{2}{*}{$1411 \mathrm{bp}$} \\
\hline & RNA-R3 & & ATATCGCTTTCCAGAGGC & \\
\hline \multirow{2}{*}{4} & RNA-F4 & \multirow{2}{*}{$50^{\circ} \mathrm{C}$} & CTCAGTCGTCTCCCGTGTC & \multirow{2}{*}{$2348 \mathrm{bp}$} \\
\hline & RNA-R4 & & CGGTCTCAAAGTCAATCCC & \\
\hline \multirow{2}{*}{5} & RNA-F5 & \multirow{2}{*}{$50{ }^{\circ} \mathrm{C}$} & GACGAGTTGAGCCTACAGA & \multirow{2}{*}{1969 bp } \\
\hline & RNA-R5 & & ATGCCTTGGAGGAGTGAA & \\
\hline \multirow[b]{2}{*}{6} & RNA-F6 & \multirow{2}{*}{$44^{\circ} \mathrm{C}$} & СССТТСАСТССТССАА & \multirow{2}{*}{$1098 \mathrm{bp}$} \\
\hline & RNA-R6 & & GAGTAATCCTGACATCCC & \\
\hline \multirow[b]{2}{*}{7} & RNA-F7 & \multirow{2}{*}{$40{ }^{\circ} \mathrm{C}$} & TACGACCGTAACAATG & \multirow{2}{*}{$957 \mathrm{bp}$} \\
\hline & RNA-R7 & & GGCTGAGGAGGAGGAG & \\
\hline \multirow[b]{2}{*}{8} & RNA-F8 & \multirow{2}{*}{$39^{\circ} \mathrm{C}$} & СТСТCATACTGCACCA & \multirow{2}{*}{$1331 \mathrm{bp}$} \\
\hline & RNA-R8 & & AAATTGCAGGGATTAAATTG & \\
\hline \multirow{2}{*}{9} & RNA-F9 & \multirow{2}{*}{$44^{\circ} \mathrm{C}$} & ACGGTGAAGTGAACGC & \multirow{2}{*}{$350 \mathrm{bp}$} \\
\hline & RNA-R9 & & TTTTCTCAAAAAGTGTGG & \\
\hline
\end{tabular}

\subsection{PCR Amplification and Sequencing}

PCR amplification was conducted with TaKaRa EX Taq DNA polymerase (TaKaRa), cDNA template, dNTP and primers following the manufacturer's protocol. The PCR was performed at $98^{\circ} \mathrm{C}$, with pre-denaturation for $10 \mathrm{~s}$, followed by 35 cycles including $94^{\circ} \mathrm{C}$ denaturation for $30 \mathrm{~s}$, annealing for $30 \mathrm{~s}$, extension at $72{ }^{\circ} \mathrm{C}$ for $30 \mathrm{~s}$ and final extension 
at $72{ }^{\circ} \mathrm{C}$ for $7 \mathrm{~min}$. The annealing temperatures were set based on the requirements of different primers (Table 1). The PCR amplicons were purified and then sequenced by the commercial sequencing company Shanghai SAN-GAN Co. Ltd. (Shanghai, China).

\subsection{Mass Spectrometry Analysis}

To identify the suspected protein(s) of potential viruses, SDS-PAGE (sodium dodecyl sulphate-polyacrylamide gel electrophoresis) of the purified viruses was first conducted, and then mass spectrometry analysis of the potential proteins of the purified virus was carried out. The sample was subjected to enzymatic hydrolysis subsequently according to the previous methods [40-42]. The digested samples were then analyzed through mass spectrometry analysis by using the Easy-nLC 1200 (Thermo Scientific, Waltham, MA, USA, P/N LC140) and Q-Exactive HF-X (Thermo Scientific). After the mass spectrum data were extracted using Proteome Discover software, the MaxQuant 1.6.1.0 was used to search the database. The search parameters were as follows: the database was the protein library derived from genomes; in trypsin digestion, the maximum missed cut was 2; the main search of precursor tolerance was $4.5 \mathrm{ppm}$; the first search of precursor tolerance was 20 ppm; methionine $(\mathrm{M})$ oxidation and asparagine $(\mathrm{N})$ deamidation were set as variable modifications as described in previous research [43].

\section{Results}

\subsection{TEM Analysis of the Potential Virus and Morphology of the Purified Virions}

TEM was used to examine the ultrathin sections of the hepatopancreas tissues of the moribund $P$. vannamei. Un-enveloped virus-like particles with a diameter of $\sim 40 \mathrm{~nm}(\mathrm{n}=31)$ were observed in the inclusions body in cytoplasm of hepatopancreatic epithelial cells (Figure 1a). Observation of the negative-stained virus particles purified from the moribund $P$. vannamei by ultracentrifugation revealed that the purified viral particles were identical in morphology with those virus-like particles in ultrathin sections of the hepatopancreas tissues (Figure 1b). The virus was tentatively named Penaeus vannamei picornavirus (PvPV) for further investigation.

\subsection{Molecular Characterization of PvPV}

Using Illumina sequencing, the potential pathogens' sequences were identified from the total RNA of the viral extracts prepared from the diseased P. vannamei sample NO. 20150715007. A total of 37,073,944 raw reads were obtained, and then 35,246,406 clean reads were kept after quality control. These reads were de novo assembled using Trinity, and virus-related contigs were submitted to Blast $\mathrm{X}$ and BlastN for primary confirmation of potential viral genomes. One potential virus with the most contigs with a whole-genome sequence of 10,550 nts in length was found, and the virus was $96 \%$ identical in genomic sequence level with the previous reported Wenzhou shrimp virus 8 (GenBank Number: KX883984.1). To confirm whole sequences of $P v P V$, primers for Sanger sequencing were designed based on the known gene sequences (Table 1). Amplification of the PvPV genome by using the designed primers, as well as $5^{\prime}$ and $3^{\prime}$ RACE methods, were performed to notarize the PvPV genome. Reconstruction of the sequences from Sanger sequencing of the amplicons (Figure 2A) indicated that the re-cloned PvPV genome was consistent with those from RNA virome sequencing (Figure 2B). 


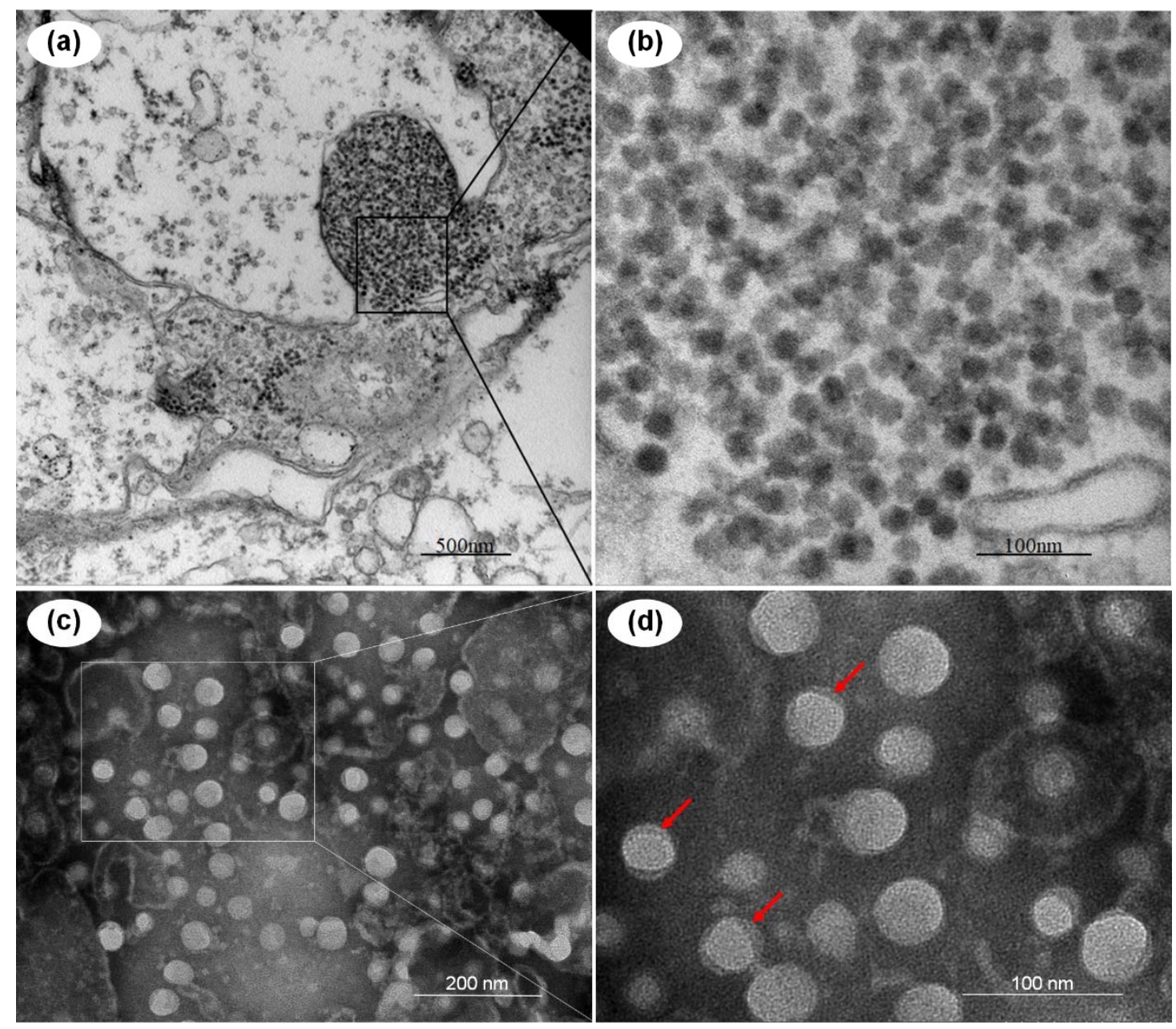

Figure 1. Transmission electron micrographs of the Penaeus vannamei picornavirus (PvPV) virions and an ultrathin section of the hepatopancreatic epithelial cells of the moribund Penaeus vannamei from the farm in Shandong, China. (a,b) Ultrathin section of hepatopancreatic epithelial cells; (c,d) purified PvPV virions; (b-d) show magnified micrographs in the corresponding framed areas of $(\mathbf{a}-\mathbf{c})$, respectively. Note the tegument of PvPV particles, indicated with red arrows. Scale bars: (a) $500 \mathrm{~nm}$, (b) $100 \mathrm{~nm}$, (c) $200 \mathrm{~nm}$, (d) $100 \mathrm{~nm}$.

Analysis of the genomic structure indicated that PvPV coded two open reading frames (ORFs). ORF1 contained three deduced conserved domains (Figure 2C), including RNAdependent RNA polymerase (RdRp domain, cd01699, nt 1880-2142, E-value $1.89 \times 10^{-39}$ ), RNA helicase (pfam00910, nt 607-703, E-value $7.91 \times 10^{-15}$ ) and PHA03247 super family (large tegument protein UL36, cl33720, nt 2, 311-2, 492, 2.19× 10-5). The deduced conserved domain of ORF2 was G-patch (G-patch domain, pfam01585, nt 664-701, E-value $7.98 \times 10^{-8}$ ). The ORF1 RNA segment (nt 290-7, 816) encoded a RdRp, RNA helicase and the large tegument protein UL36 with a total length of 2508 aa. The ORF2 RNA segment (nt 7, 825-10, 206) encoded a G-patch protein with a total length of 793 aa. 
A $10,550 \mathrm{bp}$
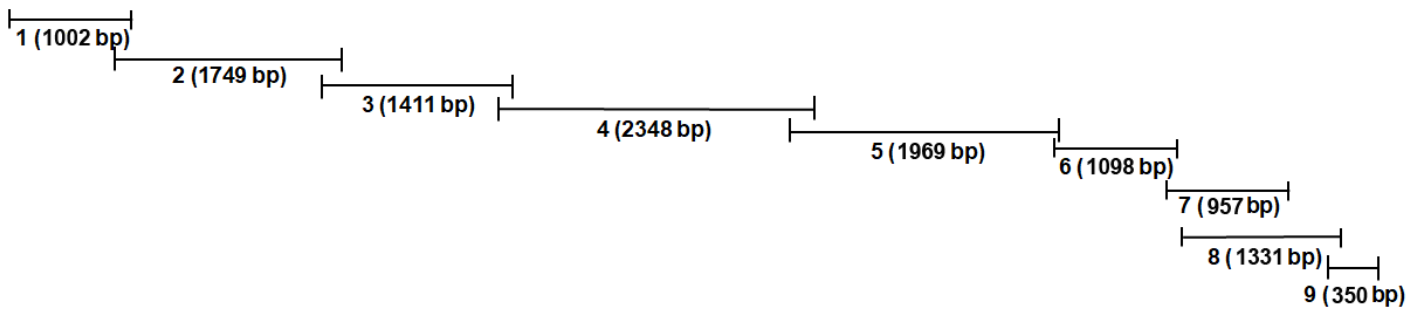

B
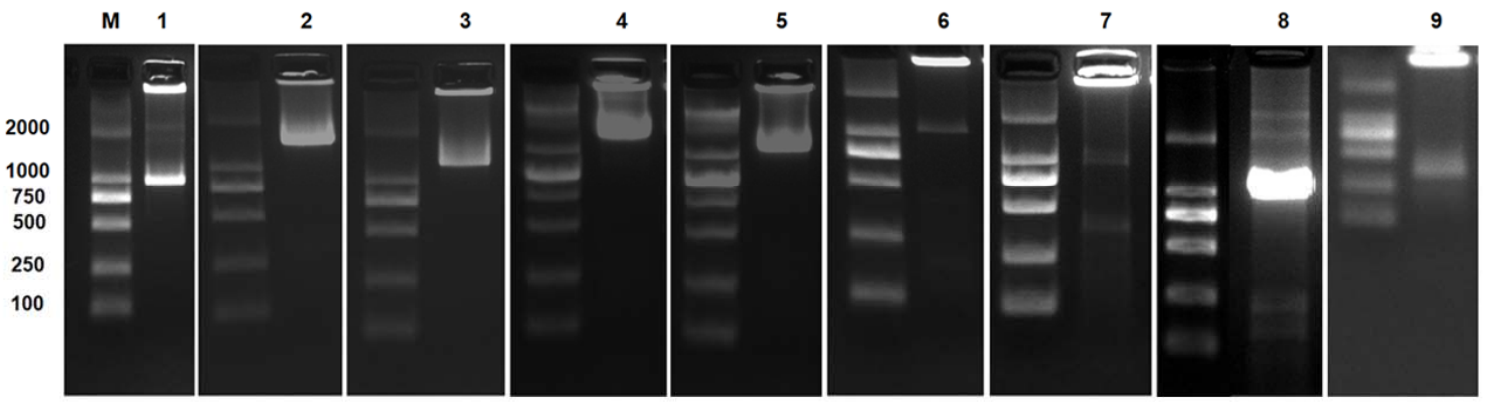

C

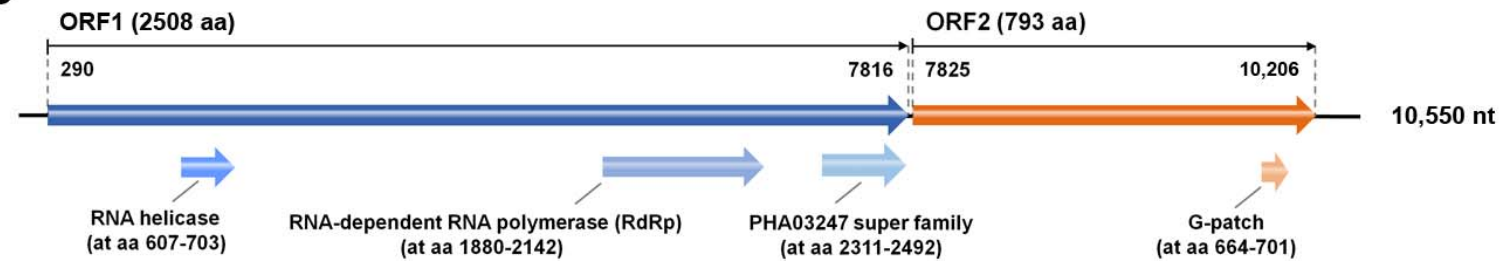

Figure 2. Assembly strategy and agarose gel electrophoresis of reverse transcription PCR (RT-PCR) products of Penaeus vannamei picornavirus (PvPV) genome sequence, and schematic presentation of the genomic open reading frame segments and conserved domains of PvPV. (A) Strategy of re-cloning and assembling the genomic open reading frame of $P v \mathrm{PV}$ by RT-PCR. The numbers 1-9 corresponding to lanes 1-9 in Figure (B) represent the expected size of the RT-PCR amplification products and indicate the position of amplicons in the PvPV genome. (B) Agarose gel electrophoresis of RT-PCR products for re-cloning of the PvPV genomic sequence. Lane M: 2000 bp marker; lanes 1-9: amplicons of PvPV genomic sequence. (C) The potential protein encoding by segments of PvPV genome was identified by using open reading frame (ORF), and the conserved protein domains were predicted using the conserved domain database (CDD) searching tool from the National Center for Biotechnology Information website.

\subsection{Identification of PvPV by Mass Spectrometry Analysis}

To identify the purified viral particles isolated from the diseased P. vannamei sample NO. 20150715007, SDS-PAGE and mass spectrometry analyses were carried out (Supplementary Figure S1). The major bands of potential viral proteins in the SDS-PAGE electrophoresis were excised from the gel and identified using mass spectrometry. The results of mass spectrometric analysis showed that the sequences of the identified peptides matched exactly with the deduced amino acids encoding by the open reading frame sequence of the PvPV genome (Figure 3). That is, mass spectrometry analysis further revealed the presence of $P v \mathrm{PV}$ in the diseased shrimp individuals. 


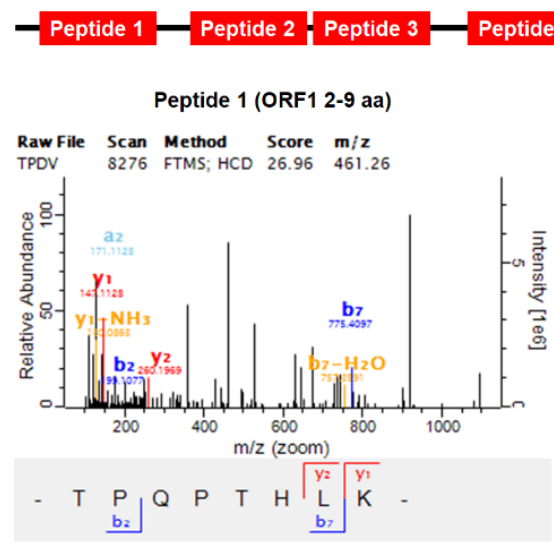

Pettide 4 (ORF1 1020-1027 aa)

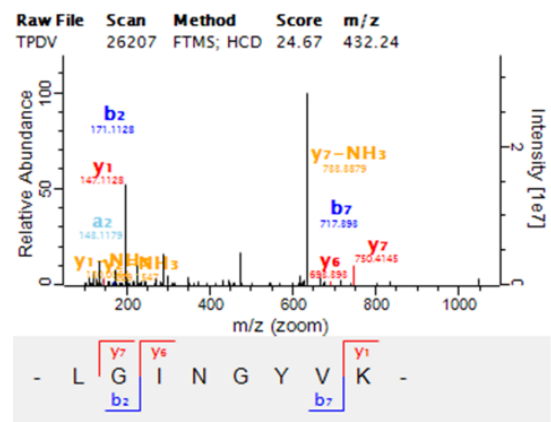

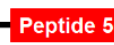

Peptide 2 (ORF1 415-420 aa)

$\begin{array}{lllll}\text { Raw File } & \text { Scan } & \text { Method } & \text { Score } & \mathbf{m} / \mathbf{z} \\ \text { TPDV } & 21690 & \text { FTMS; HCD } & 58.55 & 701.79\end{array}$

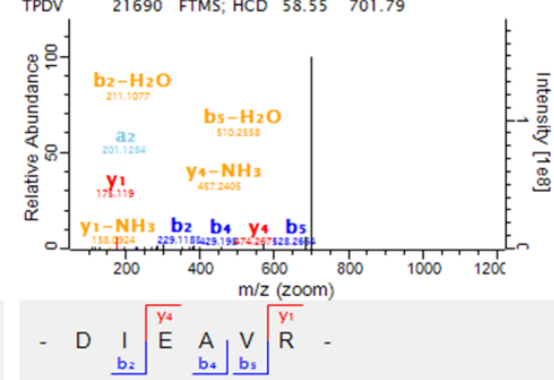

Pettide 5 (ORF1 1357-1365 aa)

Raw File Scan Method Score $\mathrm{m} / \mathbf{z}$

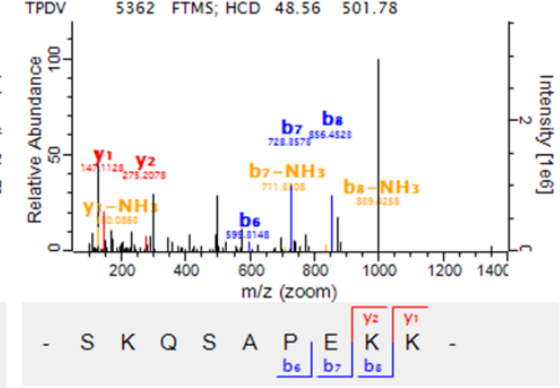

Peptide 6

$10,550 \mathrm{nt}$

Peptide 3 (ORF1 751-759 aa)

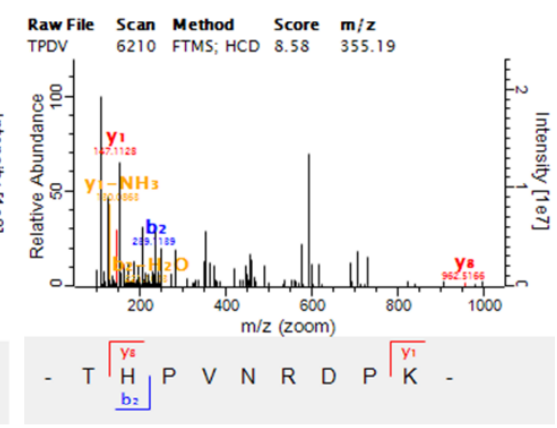

Pettide 6 (ORF2 23-30 aa)

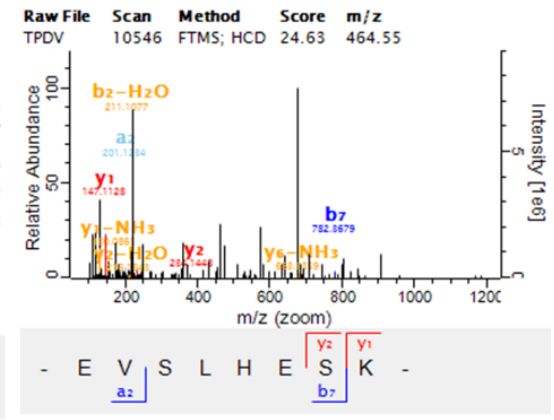

Figure 3. Mass spectrometry analysis of Penaeus vannamei picornavirus (PvPV) proteins. To identify PvPV protein by matrix-assisted laser desorption ionization time-of-flight mass spectrometry analysis, six peptides were screened and measured in the digested PvPV protein using trypsin.

\subsection{Phylogenetic Analysis}

To determine the phylogenetic relationship of the virus found in sample NO. 20150715007 with other picornaviruses, phylogenetic analyses were performed based on the genome sequences both from $\mathrm{Pv} \mathrm{PV}$ and the corresponding picornaviruses in the order Picornavirales (Figure 4). In the tree, the picornaviruses used in the multiple alignments were subdivided into eight identified families: Caliciviridae, Dicistroviridae, Iflaviridae, Marnaviridae, Picornaviridae, Polycipiviridae, Secoviridae and Solinviviridae. The potentially new picornavirus isolated from shrimp sample NO. 20150715007 was located in a new branch that belongs to the Dicistroviridae family and Picornavirales order. In the new branch, PvPV clustered together with Wenzhou shrimp virus 8 (GenBank: KX883984.1), sharing a high sequence identity of $95.43 \%$. These results of phylogenetic analysis of genome sequence indicated $P v \mathrm{PV}$ was a close relative of Wenzhou shrimp virus 8 . In a more refined evolutionary tree based on the most related viral genomes, $P v P V$ seems to be classified into the genus Aparavirus (Supplementary Figure S2). However, according to the new phylogenetic tree based on the deduced amino acids of RdRp genes from the most related viruses, both $P v P V$ and Wenzhou shrimp virus 8 may be classified into a completely new evolutionary group, which is markedly different from the family Dicistroviridae (Supplementary Figure S3). 

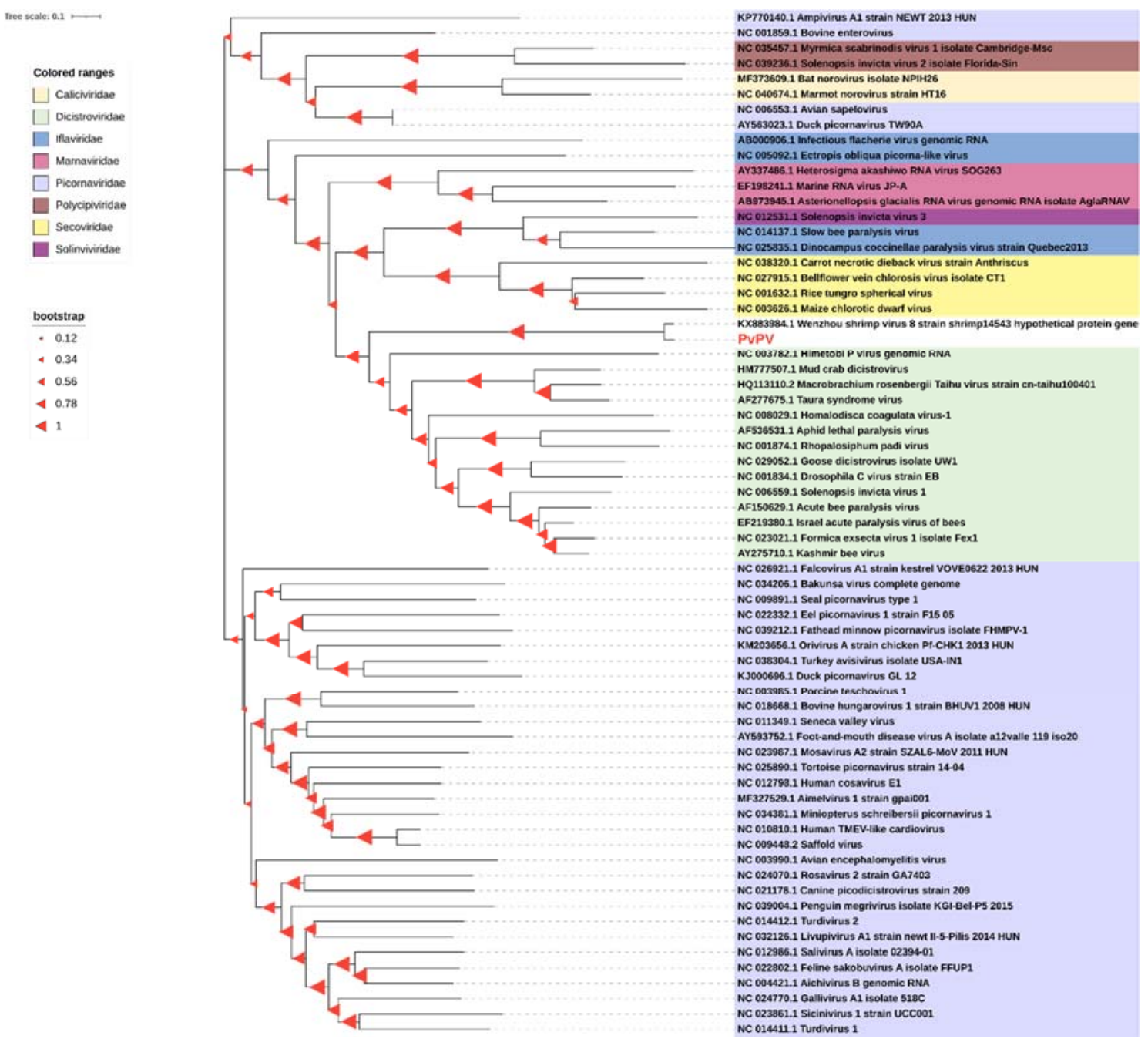

Figure 4. Phylogeny analysis of the Penaeus vannamei picornavirus (PvPV) and other picornaviruses. Phylogenetic trees based on the full-length genomic sequence were constructed using the neighbor-joining method with 1000 bootstrap replicates under the parameter of complete deletion and Poisson model using the software MEGA 6.0. The size of the red triangle symbol at the branch nodes represents the bootstrap confidence levels of the 1000 bootstrap replications obtained. Scale bar was 0.1. The PvPV is highlighted in bold red.

\section{Discussion}

Over the past decade, the world shrimp farming industry has been heavily affected by several emerging and re-emerging diseases [2,44,45]. Among the infectious diseases of cultured shrimp, certain virus-caused diseases stand out as the most significant [46]. Thus, early investigation and identification of the potential viral pathogens is very important for the prevention and control of shrimp emerging diseases. In our research, based on preliminary epidemiological investigation by our laboratory, we reported a novel picornavirus discovered in moribund oriental shrimp P. vannamei farmed in China. This novel shrimp virus was identified following study of virus morphology, viral gene sequencing, viral mass spectrometry analysis and phylogenetic analysis. The investigation results show that the genomic sequence of $P v \mathrm{PV}$, sharing high similarity with that of Wenzhou shrimp virus 8 , represents a new species.

Picornavirales is a proposed order of positive-sense single-stranded RNA viruses with a pseudo-T $=3$ virion architecture [24]. The order Picornavirales consists of eight families: Caliciviridae, Dicistroviridae, Iflaviridae, Marnaviridae, Picornaviridae, Polycipiviridae, Secoviridae and Solinviviridae [24,47]. Based on genome sequencing and phylogenetic 
analysis, PvPV proved to belong to the family Dicistroviridae in our study. The family Dicistroviridae mainly contains three genera: Aparavirus (type species: Acute bee paralysis virus), Cripavirus (type species: Cricket paralysis virus) and Triatovirus (type species: Triatoma virus) [7]. There are also some tentative members of the family Dicistroviridae. Currently, only three species of dicistroviruses have been reported in crustaceans. One was TSV in $P$. vannamei $[7,32,48,49]$, as an agent of TSV epizootics. Cumulative mortalities due to TSV epizootics have ranged from $40 \%$ to $>90 \%$ in cultured populations of postlarval (PL), juvenile and subadult P. vannamei [50]. One was mud crab dicistrovirus-1 (MCDV-1), an infection which caused $100 \%$ mortality in crabs [51]. The other was Macrobrachium rosenbergii Taihu virus (MrTV) in crustaceans, which was confirmed to be the causative agent of the larval mortality syndrome in $M$. rosenbergii [52], causing a high mortality rate of up to $80-90 \%$ [53]. The high mortality in crustaceans caused by the three species of dicistroviruses results in economic loss in aquaculture of crustaceans. This study reported a fourth dicistrovirus, $P v \mathrm{PV}$, in crustaceans, having a close relationship with the Wenzhou shrimp virus 8 (WzSV-8), MCDV-1, MrTV and TSV as shown by phylogenetic analysis. However, the potential pathogenicity of the virus is still unclear and deserves further study.

PrPV and WzSV-8 have previously been classified into the genus Aparavirus in the family Dicistroviridae according to the evolutionary tree based on viral genomes. However, according to the phylogenetic tree based on the deduced amino acids of RdRp genes from the most related viruses, $P v P V$ and WzSV-8 may be re-classified into a completely new evolutionary group markedly different from the family Dicistroviridae. In this study, compared with the RdRp and whole genomes of known viruses, the RdRp of PvPV shared higher similarity (highest at $29.79 \%$ for a matching pair with Feksystermes virus) than did the genome of PvPV (highest no more than 10\% matching pair with any known viruses). The result showed that the deduced amino acids sequences of RdRp were more conservative than the genome sequence in PvPV. Therefore, it can be deduced that the result of phylogenetic analysis based on RdRp would be more reliable than that based on the genome in $\mathrm{Pv} \mathrm{PV}$ when carrying out more refined genetic phylogeny analysis. The finding that $P v \mathrm{PV}$ may be categorized as a completely new evolutionary group markedly different from the family Dicistroviridae is thus more reliable and credible. Hence, $P v P V$ should be a new species that also represents a newly proposed genus in the Picornavirales order. This proposal will be submitted to the International Committee on Taxonomy of Viruses (ICTV) for approval.

In dicistrovirus, the RNA genome is monopartite and dicistronic with two nonoverlapping ORFs separated and flanked by the untranslated regions (UTRs) [52]. In TSV, ORF 1 contains the sequence motifs for nonstructural proteins, such as helicase, protease and RdRp. ORF 2 contains the sequences for TSV structural proteins, including the three major capsid proteins VP1, VP2 and VP3 [46]. In MrTV, the components of ORF 1 contain an RNA helicase (Hel), a RdRp and a cysteine protease. The ORF2 encodes the capsid protein, 990 amino acids in length [52]. In MCDV-1 genome, three conserved domains, including BIR (Baculovirus Inhibitor of apoptosis protein Repeat), helicase and RdRp were found with BLAST in the National Center for Biotechnology Information (NCBI) website. ORF2 of MCDV-1 encoded the capsid proteins VP1, VP2 and VP3 with 961 putative amino acids [51]. Genomic structural analysis revealed that the PvPV genome was arranged in this typical organization. In PvPV, two separated ORFs, flanked by UTRs, were identified. The 5'-proximal ORF1 encodes RdRp, helicase and UL36 (large tegument protein), while the 3'-proximal ORF2 was deduced to encode G-patch. In all +ssRNA viruses, the $R d R p$ gene is the most conserved gene. Evolution of RNA viruses is defined and clarified mostly based on RdRp phylogeny supplemented by phylogenies of other genes that are conserved in subsets of viruses, together with comparative analysis of genome organization [54]. RNA helicase A (RHA) has been shown to play a proviral role in the life cycle of many viruses [55]. All herpesviruses have a tegument, a layer of protein located between the virus capsid and membrane. Large tegument protein UL36 plays a central role in organizing the overall structure of the tegument [56]. In the pseudorabies virus (PrV), 
pUL36 is the only tegument protein analyzed to date, which is strictly essential for viral replication [57]. G-patch proteins, consisting of glycine-rich motifs, act as cofactors in RNA processing [58-60]. Similar to the genome structure of other dicistroviruses in crustaceans, the ORF1 of PvPV also includes RdRp and helicase. The ORF1 of PvPV does not include proteases, a cysteine protease, or BIR but includes the large tegument protein UL36. At the same time, a conserved domain database (CDD) search identified homologous proteins to the G-patch protein in ORF2, rather than the capsid protein, which is different from most described dicistroviruses. The existence of a G-patch protein instead of the capsid protein expands our awareness of the structural flexibility and diversity among dicistroviruses. The difference in genome sequence between $P v \mathrm{PV}$ and other dicistroviruses supports the view that $P v P V$ belongs to a new genus. Genomic structural analysis lays the foundation for further exploration of the pathogenic mechanism of PvPV.

In conclusion, $P v \mathrm{PV}$, a novel picornavirus in moribund white leg shrimp P. vannamei, was discovered and characterized as a novel member of the Dicistroviridae based on virus morphology, viral genome, viral mass spectrometry analysis and phylogenetic analysis. The discovery of PvPV expands the family of Dicistroviridae and may shed light on potential $\mathrm{Pv} \mathrm{PV}$ disease prevention and occurrence.

Supplementary Materials: The following are available online at https://www.mdpi.com/article/ 10.3390/v13122381/s1, Figure S1: Identifying PvPV proteins by SDS-PAGE (6-8\% gel). Lane M, molecular weight markers. Lane 1, the viral structural proteins of PvPV. Figure S2: Phylogeny analysis of the genome sequences of $P v \mathrm{PV}$ and representative viruses in the family Dicistroviridae. The scale bar was 0.1. Figure S3: Phylogeny analysis of the deduced amino acid sequences of RNA-dependent RNA polymerase (RdRp) gene of $P v \mathrm{PV}$ and representative viruses in the order Picornavirales. The scale bar was 0.2 .

Author Contributions: Q.Z. designed the experiments. Q.Z., S.L., T.X., C.W. and T.J. executed the experiments. Q.Z., S.L. and T.X. contributed to natural infected shrimp sampling. Q.Z., T.X. and S.L. conducted the viral genome sequencing and analyzed the viral genomic sequence. C.W. and T.X. finished the virus isolation from the farmed shrimp and undertook the photography. S.L. and T.X. performed molecular confirmation of the viral genome. S.L. analyzed the data and wrote the manuscript. Q.Z. revised the manuscript. All authors have read and agreed to the published version of the manuscript.

Funding: This work was supported by the Central Public-interest Scientific Institution Basal Research Fund, CAFS (NO. 2020TD39; 2021XT0602), Projects of International Exchange and Cooperation in Agri-culture, Ministry of Agriculture and Rural Affairs (MARA) of China-Science, Project of Species Conservation from the MARA-Marine fisheries resources collection and preservation, and Central Public-interest Scientific Institution Basal Research Fund, YSFRI, CAFS (NO. 20603022019003; 20603022020005) and Qingdao Postdoctoral Researcher Applied Research Project.

Institutional Review Board Statement: All the protocols of shrimp handling and sampling were approved by the Animal Care and Ethics Committee, Yellow Sea Fisheries Research Institute, Chinese Academy of Fishery Sciences (approval code: YSFRI-2015007).

Informed Consent Statement: Not applicable.

Data Availability Statement: The full-length genome of PvPV has been deposited in GenBank under accession number: OK662577 (10,550 nts).

Acknowledgments: The authors would like to thank Xiuhua Wang for his generous help in sampling, Yuanning Li of Shandong University for his generous help in the construction of the evolutionary tree, and Xuan Dong for his help in revising the text of the article.

Conflicts of Interest: The authors declare no conflict of interest. 


\section{References}

1. Flegel, T.W.; Lightner, D.V.; Lo, C.F.; Owens, L. Shrimp Disease Control: Past, Present and Future. Dis. Asian Aquac. VI. Fish Health Sect. Asian Fish. Soc. Manila Philipp. 2008, 505, 355-378.

2. Flegel, T.W. Historic emergence, impact and current status of shrimp pathogens in Asia. J. Invertebr. Pathol. 2012, 110, 166-173. [CrossRef] [PubMed]

3. Soto, M.A.; Lotz, J.M. Epidemiological Parameters of White Spot Syndrome Virus Infections in Litopenaeus vannamei and L. setiferus. J. Invertebr. Pathol. 2001, 78, 9-15. [CrossRef] [PubMed]

4. Soto, M.A.; Shervette, V.R.; Lotz, J.M. Transmission of white spot syndrome virus (WSSV) to Litopenaeus vannamei from infected cephalothorax, abdomen, or whole shrimp cadaver. Dis. Aquat. Org. 2001, 45, 81-87. [CrossRef] [PubMed]

5. Zhang, Q.; Liu, Q.; Liu, S.; Yang, H.; Liu, S.; Zhu, L.; Yang, B.; Jin, J.; Ding, L.; Wang, X.; et al. A new nodavirus is associated with covert mortality disease of shrimp. J. Gen. Virol. 2014, 95, 2700-2709. [CrossRef]

6. Kalagayan, H.; Kalagayan, H.; Godin, D.; Kanna, R.; Hagino, G.; Sweeney, J.; Wyban, J.; Brock, J. IHHN Virus as an Etiological Factor in Runt-Deformity Syndrome (RDS) of Juvenile Penaeus vannamei Cultured in Hawaii. J. World Aquac. Soc. 2010, 22, 235-243. [CrossRef]

7. Mayo, M.A. Virus Taxonomy-Houston 2002. Arch. Virol. 2002, 147, 1071-1076. [PubMed]

8. Tang, K.; Lightner, D. A yellow head virus gene probe: Nucleotide sequence and application for in situ hybridization. Dis. Aquat. Org. 1999, 35, 165-173. [CrossRef]

9. Lightner, D. The penaeid shrimp viral pandemics due to IHHNV, WSSV, TSV and YHV: History in the Americas and current status. In Proceedings of the 32nd Joint UJNR Aquaculture Panel Symposium, Davis and Santa Barbara, CA, USA, January 2003; pp. 17-20. Available online: https:/ / www.researchgate.net/publication/228580878_The_penaeid_shrimp_viral_pandemics_ due_to_IHHNV_WSSV_TSV_and_YHV_history_in_the_Americas_and_current_status (accessed on 20 January 2003).

10. Nunan, L.M.; Poulos, B.T.; Lightner, D.V. The detection of White Spot Syndrome Virus (WSSV) and Yellow Head Virus (YHV) in imported commodity shrimp. Aquaculture 1998, 160, 19-30. [CrossRef]

11. Zhang, H.; Wang, J.; Yuan, J.; Li, L.; Zhang, J.; Bonami, J.R.; Shi, Z. Quantitative relationship of two viruses (MrNV and XSV) in white-tail disease of Macrobrachium rosenbergii. Dis. Aquat. Org. 2006, 71, 11-17. [CrossRef]

12. Lifeng, C. 2021 Analysis of Important Aquatic Animal Diseases in China; Agriculture Press; Fishery and Fishery Administration of the Ministry of Agriculture and Rural Affairs: Beijing, China, 2021.

13. Van Hulten, M.C.; Witteveldt, J.; Peters, S.; Kloosterboer, N.; Tarchini, R.; Fiers, M.; Sandbrink, H.; Lankhorst, R.K.; Vlak, J.M. The white spot syndrome virus DNA genome sequence. Virology 2001, 286, 7-22. [CrossRef]

14. Yang, F.; He, J.; Lin, X.; Li, Q.; Pan, D.; Zhang, X.; Xu, X. Complete genome sequence of the shrimp White spot bacilliform virus. J. Virol. 2001, 75, 11811-11820. [CrossRef]

15. Xu, T.; Liu, S.; Li, X.; Zhang, Q. Genomic characterization of covert mortality nodavirus from farming shrimp: Evidence for a new species within the family Nodaviridae. Virus Res. 2020, 286, 198092. [CrossRef]

16. Rai, P.; Safeena, M.P.; Krabsetsve, K.; La Fauce, K.; Owens, L.; Karunasagar, I. Genomics, Molecular Epidemiology and Diagnostics of Infectious hypodermal and hematopoietic necrosis virus. Indian J. Virol. Off. Organ Indian Virol. Soc. 2012, 23, 203-214. [CrossRef] [PubMed]

17. Mari, J.; Poulos, B.T.; Lightner, D.V.; Bonami, J.R. Shrimp Taura syndrome virus: Genomic characterization and similarity with members of the genus Cricket paralysis-like viruses. J. Gen. Virol. 2002, 83, 915-926. [CrossRef]

18. Dong, X.; Liu, S.; Zhu, L.; Wan, X.; Liu, Q.; Qiu, L.; Zou, P.; Zhang, Q.; Huang, J. Complete genome sequence of an isolate of a novel genotype of yellow head virus from Fenneropenaeus chinensis indigenous in China. Arch. Virol. 2017, 162, 1149-1152. [CrossRef] [PubMed]

19. Jeeva, S.; Kang, S.W.; Lee, Y.S.; Jang, I.K.; Seo, H.C.; Choi, T.J. Complete nucleotide sequence analysis of a Korean strain of hepatopancreatic parvovirus (HPV) from Fenneropenaeus chinensis. Virus Genes 2012, 44, 89-97. [CrossRef]

20. Sukhumsirichart, W.; Attasart, P.; Boonsaeng, V.; Panyim, S. Complete nucleotide sequence and genomic organization of hepatopancreatic parvovirus (HPV) of Penaeus monodon. Virology 2006, 346, 266-277. [CrossRef]

21. Tang, K.F.J.; Pantoja, C.R.; Redman, R.M.; Navarro, S.A.; Lightner, D.V. Ultrastructural and sequence characterization of Penaeus vannamei nodavirus (PvNV) from Belize. Dis. Aquat. Org. 2011, 94, 179-187. [CrossRef]

22. Poulos, B.; Tang, K.; Pantoja, C.; Bonami, J.R.; Lightner, D. Purification and characterization of infectious myonecrosis virus of penaeid shrimp. J. Gen. Virol. 2006, 87, 987-996. [CrossRef] [PubMed]

23. Munnink, B.B.O.; Cotten, M.; Deijs, M.; Jebbink, M.F.; Bakker, M.; Farsani, S.M.J.; Canuti, M.; Kellam, P.; van der Hoek, L. A novel genus in the order Picornavirales detected in human stool. J. Gen. Virol. 2015, 96, 3440-3443. [CrossRef]

24. Le Gall, O.; Christian, P.; Fauquet, C.M.; King, A.M.Q.; Knowles, N.J.; Nakashima, N.; Stanway, G.; Gorbalenya, A.E. Picornavirales, a proposed order of positive-sense single-stranded RNA viruses with a pseudo-T = 3 virion architecture. Arch. Virol. 2008, 153, 715. [CrossRef]

25. Argos, P.; Kamer, G.; Nicklin, M.J.; Wimmer, E. Similarity in gene organization and homology between proteins of animal picornaviruses and a plant comovirus suggest common ancestry of these virus families. Nucl. Acid. Res. 1984, 12, 7251-7267. [CrossRef]

26. Franssen, H.; Leunissen, J.; Goldbach, R.; Lomonossoff, G.; Zimmern, D. Homologous sequences in non-structural proteins from cowpea mosaic virus and picornaviruses. EMBO J. 1984, 3, 855-861. [CrossRef] 
27. Goldbach, R.W. Molecular evolution of plant rna viruses. Annu. Rev. Phytopathol. 1986, 24, 289-310. [CrossRef]

28. Goldbach, R. Genome similarities between plant and animal RNA viruses. Microbiol. Sci. 1987, 4, 197-202.

29. Goldbach, R.; Wellink, J. Evolution of plus-strand RNA viruses. Intervirology 1988, 29, 260-267. [CrossRef]

30. Rossmann, M.G.; Johnson, J.E. Icosahedral RNA Virus Structure-Annual Review of Biochemistry. Annu. Rev. Biochem. 1989, 58, 533. [CrossRef] [PubMed]

31. Liljas, L.; Tate, J.; Lin, T.; Christian, P.; Johnson, J.E. Evolutionary and taxonomic implications of conserved structural motifs between picornaviruses and insect picorna-like viruses. Arch. Virol. 2002, 147, 59-84. [CrossRef] [PubMed]

32. Hasson, K.W.; Lightner, D.V.; Poulos, B.T.; Redman, R.M.; White, B.L.; Brock, J.A.; Bonami, J.R. Taura syndrome in Penaeus vannamei: Demonstration of a viral etiology. Dis. Aquat. Org. 1995, 23, 115-126. [CrossRef]

33. Lightner, D.V. Epizootiology, distribution and the impact on international trade of two penaeid shrimp viruses in the Americas. Rev. Sci. Tech. 1996, 15, 579-601. [CrossRef]

34. Overstreet, R.M.; Lightner, D.V.; Hasson, K.W.; McIlwain, S.; Lotz, J.M. Susceptibility to Taura Syndrome Virus of Some Penaeid Shrimp Species Native to the Gulf of Mexico and the Southeastern United States. J. Invertebr. Pathol. 1997, 69, 165-176. [CrossRef]

35. Hasson, K.W.; Lightner, D.V.; Mari, J.; Bonami, J.R.; Poulos, B.T.; Mohney, L.L.; Redman, R.M.; Brock, J.A. The geographic distribution of Taura Syndrome Virus (TSV) in the Americas: Determination by histopathology and in situ hybridization using TSV-specific cDNA probes. Aquaculture 1999, 171, 13-26. [CrossRef]

36. Yu, C.I.; Song, Y.L. Outbreaks of Taura Syndrome in Pacific White Shrimp Penaeus vannamei Cultured in Taiwan. Fish Pathol. 2000, 35, 21-24. [CrossRef]

37. Bonami, J.R.; Shi, Z.; Qian, D.; Sri Widada, J. White tail disease of the giant freshwater prawn, Macrobrachium rosenbergii: Separation of the associated virions and characterization of MrNV as a new type of nodavirus. J. Fish Dis. 2010, 28, 23-31. [CrossRef] [PubMed]

38. Grabherr, M.G.; Haas, B.J.; Yassour, M.; Levin, J.Z.; Thompson, D.A.; Amit, I.; Adiconis, X.; Fan, L.; Raychowdhury, R.; Zeng, Q.; et al. Full-length transcriptome assembly from RNA-Seq data without a reference genome. Nat. Biotechnol. 2011, $29,644-652$. [CrossRef] [PubMed]

39. Tamura, K.; Stecher, G.; Peterson, D.; Filipski, A.; Kumar, S. MEGA6: Molecular Evolutionary Genetics Analysis Version 6.0. Mol. Biol. Evol. 2013, 30, 2725-2729. [CrossRef]

40. Shevchenko, A.; Jensen, O.N.; Podtelejnikov, A.V.; Sagliocco, F.; Wilm, M.; Vorm, O.; Mortensen, P.; Shevchenko, A.; Boucherie, H.; Mann, M. Linking genome and proteome by mass spectrometry: Large-scale identification of yeast proteins from two dimensionalgels. Proc. Natl. Acad. Sci. USA 1996, 93, 14440-14445. [CrossRef]

41. Calderaro, A.; Arcangeletti, M.C.; Rodighiero, I.; Buttrini, M.; Gorrini, C.; Motta, F.; Germini, D.; Medici, M.-C.; Chezzi, C.; De Conto, F. Matrix-assisted laser desorption/ionization time-of-flight (MALDI-TOF) mass spectrometry applied to virus identification. Sci. Rep. 2014, 4, 6803. [CrossRef]

42. Xiu, L.; Zhang, C.; Wu, Z.; Peng, J. Establishment and Application of a Universal Coronavirus Screening Method Using MALDI-TOF Mass Spectrometry. Front. Microbiol. 2017, 8, 1510. [CrossRef]

43. Zhao, L.; Zhang, Z.; Wang, M.; Sun, J.; Li, H.; Malakar, P.K.; Liu, H.; Pan, Y.; Zhao, Y. New insights into the changes of proteome and microbiome of shrimp (Litopenaeus vannamei) stored in acidic electrolyzed water ice. J. Agric. Food Chem. 2018, 66, $4966-4976$. [CrossRef]

44. Yong, C.Y.; Yeap, S.K.; Omar, A.R.; Tan, W.S. Advances in the study of nodavirus. PeerJ 2017, 5, e3841. [CrossRef]

45. Kibenge, F.S. Emerging viruses in aquaculture. Curr. Opin. Virol. 2019, 34, 97-103. [CrossRef] [PubMed]

46. Lightner, D.V. Virus diseases of farmed shrimp in the Western Hemisphere (the Americas): A review. J. Invertebr. Pathol. 2011, 106, 110-130. [CrossRef] [PubMed]

47. Carstens, B. Virus Taxonomy: Ninth Report of the International Committee on Taxonomy of Viruses; King, A.M.Q., Lefkowitz, E., Adams, M.J., Carstens, E.B., Eds.; Elsevier: Amsterdam, The Netherlands, 2011; p. 1338.

48. Bonami, J.R.; Hasson, K.W.; Mari, J.; Poulos, B.T.; Lightner, D.V. Taura syndrome of marine penaeid shrimp: Characterization of the viral agent. J. Gen. Virol. 1997, 78, 313-319. [CrossRef] [PubMed]

49. Hasson, K.W.; Lightner, D.V.; Mohney, L.L.; Redman, R.M.; Poulos, B.T.; White, B.M. Taura syndrome virus (TSV) lesion development and the disease cycle in the Pacific white shrimp Penaeus vannamei. Dis. Aquat. Org. 1999, 36, 81-93. [CrossRef]

50. Brock, J.A.; Gose, R.; Lightner, D.V.; Hasson, K. An overview on Taura syndrome, an important disease of farmed. Swimming through troubled water. In Proceedings of the Special Session on Shrimp Farming, San Diego, CA, USA, 1-4 February 1995.

51. Guo, Z.X.; He, J.G.; Xu, H.D.; Weng, S.P. Pathogenicity and complete genome sequence analysis of the mud crab dicistrovirus-1. Virus Res. 2013, 171, 8-14. [CrossRef]

52. Pan, X.; Cao, Z.; Yuan, J.; Shi, Z.; Yuan, X.; Lin, L.; Xu, Y.; Yao, J.; Hao, G.; Shen, J. Isolation and Characterization of a Novel Dicistrovirus Associated with Moralities of the Great Freshwater Prawn, Macrobrachium rosenbergii. Int. J. Mol. Sci. 2016, 17, 204. [CrossRef] [PubMed]

53. Pan, X.; Gao, Q.; Shen, J.; Xu, T. 14-3-3 is a VP3-binding protein involved in Macrobrachium rosenbergii Taihu virus infection in shrimp. Dev. Comp. Immunol. 2021, 122, 104139. [CrossRef]

54. Koonin, E.V.; Wolf, Y.I.; Nagasaki, K.; Dolja, V.V. The Big Bang of picorna-like virus evolution antedates the radiation of eukaryotic supergroups. Nat. Rev. Microbiol. 2008, 6, 925-939. [CrossRef]

55. Lee, T.; Pelletier, J. The biology of DHX9 and its potential as a therapeutic target. Oncotarget 2016, 7, 42716. [CrossRef] 
56. Newcomb, W.W.; Brown, J.C. Structure and capsid association of the herpesvirus large tegument protein UL36. J. Virol. 2010, 84, 9408. [CrossRef] [PubMed]

57. Fuchs, W.; Klupp, B.G.; Granzow, H.; Mettenleiter, T.C. Essential Function of the Pseudorabies Virus UL36 Gene Product Is Independent of Its Interaction with the UL37 Protein. J. Virol. 2004, 78, 11879-11889. [CrossRef] [PubMed]

58. Studer, M.K.; Ivanović, L.; Weber, M.E.; Marti, S.; Jonas, S. Structural basis for DEAH-helicase activation by G-patch proteins. Proc. Natl. Acad. Sci. USA 2020, 117, 7159-7170. [CrossRef] [PubMed]

59. Sloan, E.K.; Bohnsack, M.T. Unravelling the Mechanisms of RNA Helicase Regulation. Trends Biochem. Sci. 2018, 43, 237-250. [CrossRef]

60. Aravind, L.; Koonin, E.V. G-patch: A new conserved domain in eukaryotic RNA-processing proteins and type D retroviral polyproteins. Trends Biochem. Ences 1999, 24, 342-344. [CrossRef] 